\title{
Bladder Pain Syndrome (Interstitial Cystitis) Consensus 2019: The Report of the Turkish Continence Society Bladder Pain Syndrome/ Interstitial Cystitis Working Group
}

\author{
Mesane Ağrısı Sendromu (Interstisyel Sistit) Konsensus 2019: Türkiye - Kontinans Derneği \\ Mesane Ağrısı Sendromu/Interstisyel Sistit Çalışma Grubu Raporu
}

\author{
(D) Taner Koçak1, (D) Ömer Acar2, (D) Fatih Tarhan33, (D) Tzevat Tefik1, (D) Tayfun Mevlüt Oktar1,2, (D) Tufan Tarcan4,2 \\ 1 İstanbul University, İstanbul Faculty of Medicine, Department of Urology, İstanbul, Turkiye \\ ${ }^{2}$ Koç University Faculty of Medicine, Department of Urology, istanbul, Turkiye \\ 3istanbul Dr. Lütfi Kırdar Kartal Training and Research Hospital, Clinic of Urology, İstanbul, Turkiye \\ 4Marmara University Faculty of Medicine, Department of Urology, İstanbul Turkiye
}

\begin{abstract}
Bladder pain syndrome is an important chronic pain syndrome which seriously reduces the patients' quality of life. It is a diagnosis of exclusion. It is defined as a clinical diagnosis composed of chronic ( $>6$ months) pain/pressure/discomfort that is primarly perceived from the bladder and/or pelvis, and accompanied by urgency and/or frequency of urination. Throughout this paper, the definition, characteristic features, diagnostic tests and attempts, interpretation of the findings and the different treatment algorithms suggested by different organizations will be discussed.
\end{abstract}

Keywords: Bladder Pain syndrome, Interstitial cystitis, Chronic pelvic pain

Öz

Mesane ağrısı sendromu, hastaların yaşam kalitesini ciddi şekilde azaltan önemli bir kronik ağrı sendromudur. Bir dışlama tanısıdır. Öncelikle, mesane ve/veya pelviste hissedilen ve sıkışma ve/veya pollakürinin de eşlik ettiği, kronik (>6 ay) tarzda, ağrı/basınç/rahatsızlık hissi olarak kendini gösteren klinik bir tablodur. Bu yazıda tanımı, karakteristik özellikleri, tanı testleri ve girişimleri, bulguların yorumlanması ve farklı kuruluşların önerdiği farklı tedavi algoritmaları tartışılacaktır.

Anahtar Kelimeler: Mesane ağrısı sendromu, İntertisyel sistit, Kronik pelvik ağrı

\section{Introduction}

Bladder pain syndrome (BPS) is an important chronic disease without a specific etiologic explanation that requires a high index of suspicion for its clinical diagnosis. It is primarily a diagnosis of exclusion (1). After excluding diseases with similar presentations, BPS/interstitial cystitis (IC) is diagnosed clinically when symptoms comprise chronic (>6 months) pain/pressure/ discomfort that is perceived to be primarily originating from the bladder and/or pelvis, and accompanied by urgency and/ or frequency of urination $(1,2)$. There is no consensus regarding the nomenclature, definition and optimal management strategy of BPS/IC (3).

Recently, patients with Hunner lesions have been terminologically categorised as "Classical IC" or "BPS type 3C" that implied a BPS/ IC subtype with distinct pathological and endoscopic features and more severe symptomatology $(3,4)$. In an effort to enhance the recognition and comprehension and to align with insurance requirements, naming this disease as BPS/IC (rather than BPS) is advocated. Throughout this paper, the term BPS/IC will be used to imply BPS.

Correspondence: Tzevat Tefik MD, İstanbul University, İstanbul Faculty of Medicine, Department of Urology, İstanbul, Turkiye E-mail: tztefik@istanbul.edu.tr ORCID-ID: orcid.org/0000-0002-1398-8332

Received: 22.09.2020

Accepted: 11.11 .2020

Cite this article as: Koçak T, Acar O, Tarhan F, Tefik T, Oktar TM, Tarcan T. Bladder Pain Syndrome (Interstitial Cystitis) Consensus 2019: The Report of the Turkish Continence Society Bladder Pain Syndrome/Interstitial Cystitis Working Group. J Urol Surg 2020;7(4):251-262.

๑Copyright 2020 by the Association of Urological Surgery / Journal of Urological Surgery published by Galenos Publishing House. 


\section{Epidemiology}

Owing to the intricacies surrounding its clinical diagnosis and non-standardised management, epidemiological studies about BPS/IC have generated somewhat conflicting and controversial results. The European Association of Urology (EAU) guidelines have reported a prevalence of $0.06 \%-30 \%$ (5), while in the US it ranges between $0.067 \%$ and $2 \%(6-9)$. The more recent US-based RAND study reported a prevalence rate of 2.9\%- $4.2 \%$ (10). The prevalence in women and men ranged between $0.004 \%-11.2 \%$ and $0.01 \%-6.2 \%$, respectively $(11,12)$. The prevalence in children was noted to be extremely low (13). Warren has proposed a familial background for BPS/IC (14).

According to the literature, the incidence of BPS/IC is in the range of 1-15/100,000/year (2). EAU guidelines have reported an incidence between $0.005 \%$ and $0.05 \%$ (5). The incidence in women and men ranged between $1.221 / 100,000 /$ year and 0.64/100,000/year, respectively (15-17).

Female to male ratio of BPS/IC is $5-10: 1(11,16,18,19)$. A variation based on race or ethnicity probably exists (20-22).

\section{Characteristics and Natural Course of BPS/IC}

Patients diagnosed with BPS/IC frequently exhibit extravesicular symptom constellations or syndromes (2,23-25). Fibromyalgia, chronic fatigue syndrome, temporomandibular disorder and irritable bowel syndrome are among the common diagnoses that accompany BPS/IC (26-33). Similarly, systemic lupus erythematosus, Sjogren's syndrome, Sicca syndrome and allergic conditions may coexist in patients diagnosed with BPS/IC (18,30,33-39). The prevalence of pelvic pain, vulvar pain, headache and lower back problems have been reported to be higher in BPS/IC patients (30-32,38-40). Diagnoses like fibromyalgia, migraine, temporomandibular joint disorder and depression are more frequent in patients without characteristic bladder lesions when compared to those with BPS/IC type 3C (41). Psychological disturbances such as depression, anxiety and panic disorder have a higher prevalence in patients diagnosed with BPS/IC $(31,32,38,39,42-45)$. Sexual dysfunction is common in females with BPS/IC (46-48). A negative correlation has been observed between diabetes mellitus and BPS/IC (33).

BPS/IS is commonly diagnosed in the $4^{\text {th }}$ decade of life and later (17). It has a subacute onset with the classical symptom complex being evident over a rather short period of time. BPS/ IC is a progressive disease with evolution into its final phase in approximately 5 years after which no significant alteration in symptom severity is usually expected (49). Symptomatic fluctuation is commonly seen with BPS/IC (2). Despite the fluctuating pattern of symptoms, overall disease severity does not exhibit significant long-term variation (50). Some patients may experience phenotypic progression from an organ-specific disease to a regional or generalised pain syndrome $(38,51,52)$.

\section{Diagnosis}

As described above, diagnosing BPS is not straightforward due to the variations in symptomatic presentation and lack of concrete diagnostic criteria. Despite being composed of fundamental elements like careful history taking and physical examination; and objective assessment methods such as cystoscopy and hydrodistension, bladder biopsy and urodynamic study, the diagnostic algorithm of BPS/IC is far from ideal. Diagnosis of BPS/IC requires exclusion of diseases with similar presentations and a high index of suspicion based on the clinical experience of the physician.

\section{History}

Characteristic features of the pain, triggering factors, accompanying lower urinary tract symptoms, and other symptoms that may be related to pelvic organs must be questioned during history taking. Common to all guidelines, the diagnosis of BPS/IC necessitates the presence of pain/pressure/ discomfort perceived to be originating from the bladder and accompanying lower urinary tract symptoms, such as increased daytime and/or nocturnal urinary frequency and the exclusion of diseases that may be responsible for a similar symptomatology (5).

Definition and accurate characterisation of the pain is vital to the diagnosis. Patients usually relate this pain, pressure, or discomfort to their bladder that commonly increases with bladder fullness. Pain is most frequently localised to the suprapubic region, and migration to the thigh, vagina and rectum is not uncommon.

The diseases that need to be excluded include; bladder cancer or carcinoma in situ, specific and non-specific urogenital infections, malakoplakia, radiotherapy/chemotherapy involving or targeting pelvis, bladder stones, bladder neck contracture, distal ureteric stone, cystocele, rectocele, urethral diverticulum, endometriosis, vaginal atrophy, vulvodynia, vaginal candidiasis, gynaecological malignancies such as cervical, uterine or ovarian cancer, prostate cancer, benign prostatic hyperplasia, overactive bladder, chronic prostatitis and pudendal nerve entrapment.

Since, pain is the main parameter that needs to be assessed while evaluating treatment response, it must be graded before initiating the treatment in an effort to monitor symptomatic improvement. The most reliable methods for this are visual analogue score (pain scores ranging from 1 to 10) and the 5-item verbal assessment (no pain, mild, moderate, severe, very severe pain) (5).

Following general physical examination, some diagnostic tests and procedures may need to be conducted. 


\section{Laboratory Tests}

Urine analysis and culture (if needed, based on urine analysis findings) must be done in all patients. Patients at risk for bladder cancer should be evaluated by urine cytology. It is recommended to do vaginal and endocervical culture to rule out genital tract infection in women.

\section{Cystoscopy}

Cystoscopy in BPS/IC is an integral part of the evaluation and serves to exclude other diseases of the bladder and detect glomerulations or Hunner's lesions. Glomerulations are defined as petechial mucosal haemorrhages that occur after bladder distension (Figure 1). This oozing type of capillary bleeding may look like a "waterfall" and its intensity may impair endoscopic vision. The term "Hunner's ulcer" is replaced by "Hunner's lesion" since the lesion being described is not in the form of a true ulcer but rather is composed of an inflammatory reaction. Hunner's lesion is defined by a well-circumscribed hyperaemic mucosal region with a central scar that is adherent to a fibrin layer or coagulum and radially oriented capillaries (Figure 2). In addition to inspecting for suspicious lesions, the cystoscopy for BPS/IC workup should involve random mucosal biopsies from 3 different regions of the bladder to rule out diagnoses like carcinoma in situ, eosinophilic cystitis and tuberculous cystitis. Histopathological examination of the biopsy sample(s) obtained from Hunner's lesion (if present) usually reveals a chronic inflammatory reaction characterised by the infiltration of lymphocytes, plasma cells, macrophages, neutrophilic and eosinophilic granulocytes and an abundance of mast cells. In general, the presence of Hunner's lesion is associated with more severe symptomatology and a decreased bladder capacity $(3,53)$.
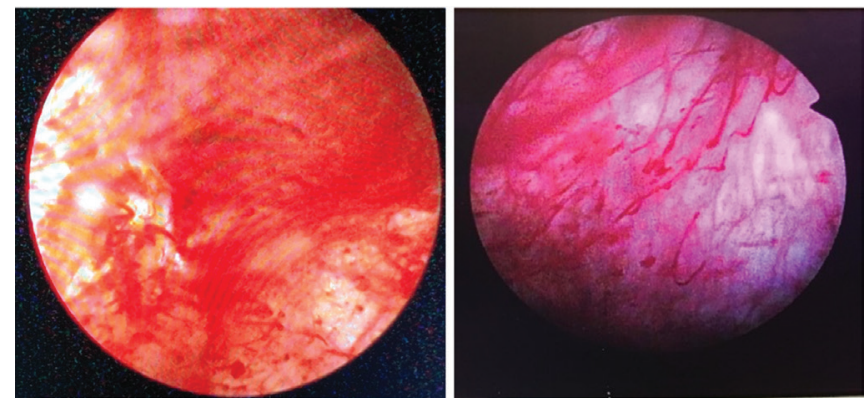

Figure 1. Cystoscopic view of a glomerulation
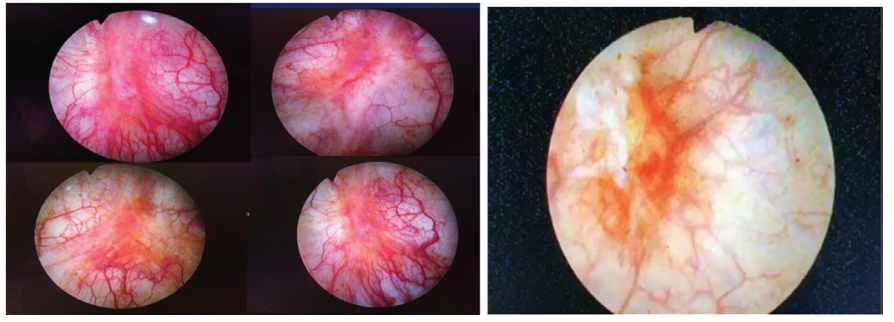

Figure 2. Cystoscopic view of a Hunner's lesion
ESSIC (International Society for the study of BPS) guidelines recommend cystoscopy and hydrodistension in order to classify patients with BPS (54) (Table 1). Similarly, EAU guidelines stand in favour of cystoscopy under general anaesthesia to define BPS/IC subtypes according to ESSIC criteria (Grade of recommendation: strong) (5). ESSIC classification of cystoscopic findings is defined as follows: "Grade 0 , normal appearing mucosa"; "Grade I, petechial bleeding in at least 2 quadrants"; "Grade II, submucosal bleeding covering a wide area (ecchymosis)"; "Grade III, diffuse mucosal bleeding"; and "Grade IV, disturbed integrity of the mucosal lining $(+/$ - bleeding/oedema)" $(3,54)$.

\section{Urodynamic Studies}

There is no consensus regarding the indications and utility of urodynamic studies in the workup of BPS. Generally, these are reserved for complex cases $(3,55)$.

\section{Potassium Sensitivity Test (Parson's Test)}

Parson's test is used to assess the permeability of bladder epithelium to potassium. However, a positive test result is inadequate in elucidating the underlying pathophysiological mechanism as it is unable to discriminate between the increased permeability of the mucosal lining and the hypersensitivity of regional afferent nerves.

\section{Biomarkers}

Several biomarkers such as, substance $P$, uroplakin III- $\delta 4$, interleukin-6, cyclic guanosine monophosphate, uromodulin, kininogens, inter- $\alpha$-trypsin inhibitor heavy chain $\mathrm{H} 4$, nitric oxide, nerve growth factor, heparin-binding epidermal growth factor-like growth factor (HB-EGF) have been tested within the context of BPS/IC. However, only antiproliferative factor (APF) has been identified as a potential diagnostic tool (56-59). APF is apparently released from the damaged bladder epithelial cells and it prevents self-regeneration of the mucosal lining. Patients with BPS/IC have increased urinary levels of APF.

GP-51 is a glycoprotein that can be detected in transitional epithelial cells and urine. Moskowitz et al. (56) have demonstrated decreased GP-51 immunostaining in the bladder

Table 1. ESSIC classification of BPS according to cystoscopy, hydrodistension and biopsy results

\begin{tabular}{|l|l|l|l|l|}
\hline & \multicolumn{4}{|l|}{ Cystoscopy and Hydrodistension } \\
\hline & Not done & Normal & Glomerulation & $\begin{array}{l}\text { Hunner's } \\
\text { lesion }\end{array}$ \\
\hline Biopsy & & & & \\
\hline Not done & XX & $1 \mathrm{X}$ & $2 \mathrm{X}$ & $3 \mathrm{X}$ \\
\hline Normal & XA & 1A & 2A & $3 \mathrm{~A}$ \\
\hline Insufficient & XB & 1B & 2B & $3 B$ \\
\hline Positive & XC & 1C & 2C & $3 \mathrm{C}$ \\
\hline BPS: Bladder pain syndrome & \multicolumn{5}{l}{} \\
\hline
\end{tabular}


biopsy samples of BPS/IC patients. Despite being inferior to APF, GP-51's specificity for the diagnosis of BPS/IC is noteworthy, making it a promising biomarker that can be used in the workup of BPS/IC.

In conclusion, while the ideal diagnostic algorithm of BPS/IC continues to be debatable, exclusion of similar diseases is a must.

Cystoscopy, urodynamic studies, potassium sensitivity test and some biomarkers may be used as adjuncts to history and physical examination for the diagnosis of BPS/IC. Except some of the cystoscopic findings and few of the biomarkers that are still under investigation, none of the diagnostic tests have specific findings attributable to BPS/IC. Consequently, the diagnosis of BPS/IC requires the recognition of specific symptom combinations and exclusion of other diagnoses that may lead to a similar clinical Picture (Table 2).

\section{Treatment}

Treatment of BPS/IC should aim at improvement in symptoms and quality of life while minimising the related side effects or complications. It is important to note that cure is not possible with the available options, and the ideal treatment requires a multidisciplinary approach. Generally, individualising treatment pathways and making treatment-related decisions based on the clinical phenotype will increase the success rates (Table 3 ) $(60,61)$.

Treatment recommendations stated in clinical guidelines and the grades of recommendation assigned to each treatment option are summarised in Tables 4, 5 and 6 (62).

Current treatment of BPS/IC involves initiation with conservative options and progression to more invasive modalities depending on the degree of improvement. Constituents of this step-wise approach exhibit differences between guidelines. Tables 7 and 8 summarise the treatment recommendations of $\mathrm{ICl}$ and AUA, respectively.

Recommendations of American Urological Association regarding the treatment of BPS/IC (63):

\section{Step 1: Conservative Treatment Options}

Patient education, diet advices, behavioural modifications, revisiting voiding habits, psychosocial support, pelvic floor physiotherapy, acupuncture and trigger point injections constitute the conservative treatment options for BPS/IC. With only patient counselling and psychological support, a symptomatic improvement in the range of $45 \%-50 \%$ can be expected (64). Minimising the amount of dietary consumables (coffee, tea, sodas, alcohol, apple, apricot, banana, peach, citrus, tomato, hot and spicy food, vinegar, artificial sweetener, etc.) that may trigger BPS/IC-related symptoms is highly recommended $(61,65)$.
Timed voiding and manoeuvres that can suppress the urge to void can help with reducing the frequency of urination, increasing bladder capacity and counteracting the desire to void that is provoked by urgency and/or pain (66). It is possible to achieve symptomatic improvement in $45 \%-88 \%$ of the patients with behavioural modifications (67).

Several psychosocial problems, such as depression and anxiety, may arise due to the chronic nature of BPS/IC (68). Stress management strategies, such as regular physical exercise, meditation and yoga may serve well to tackle the psychological burden of BPS/IC (69).

Patients who exhibit trigger point tenderness in the pelvic floor may benefit from physiotherapy (+/- biofeedback), myofascial release, or intravaginal massage. Physical therapy that is done by pelvic floor physiotherapists, can lead to symptomatic improvement in 50\%-62\% of the patients $(70,71)$.

\section{Step 2}

\section{2.a. Oral Treatment Options}

\section{Amitriptyline}

Placebo-controlled studies have reported superior results in terms of symptomatic improvement with a 4-month treatment course of amitriptyline (63\% vs $4 \%$ ). The incidence of side effects was significantly higher in the amitriptyline group than in the placebo arm (92\% vs $21 \%)$ (72). Less than half of the patients can tolerate the threshold dose of amitriptyline (50 $\mathrm{mg}$ and above) that is necessary to obtain clinically meaningful results (73).

\section{Cimetidine}

Thilagarajah et al. (74) have shown that cimetidine is superior to placebo for symptomatic improvement, with a side effect profile similar to that of placebo.

\section{Hydroxyzine}

The randomised controlled study that investigated the efficacy of hydroxyzine has demonstrated insignificant differences between the placebo and hydroxyzine groups (13\% vs $23 \%$, respectively), while hydroxyzine + pentosan polysulphate (PPS) combination performed better than PPS monotherapy (40\% vs $28 \%$, respectively) (75).

\section{Pentosan Polysulphate}

Oral PPS is approved by the Food and Drug Administration (FDA) for the treatment of BPS/IC. It acts by replenishing the deficient glycosaminoglycan (GAG) layer of the bladder. It also inhibits the histamine release from mast cells and has anti-inflammatory properties. The recommended dose is $300 \mathrm{mg} /$ day (100 mg, TID) according to the pivotal placebo-controlled studies. 
Table 2. Management algorithm of BPS/IC. $(2,3)$

\section{BLADDER PAIN SYNDROME-BPS/IC}

Chronic pain/pressure/discomfort that is perceived to be primarily originating from the bladder and/or pelvis, and accompanied by at least one lower urinary tract symptom such as urgency or frequency of urination.

\section{Exclusion of confusable diseases:}

History, physical examination

Urine analysis, urine culture, tuberculosis culture (if indicated)

PSA (males, $>40$ years of age)

Uroflowmetry and postvoid residual urine measurement

Questionnaires

Cystoscopy and hydrodistension (if indicated)

Urodynamic study (if indicated)
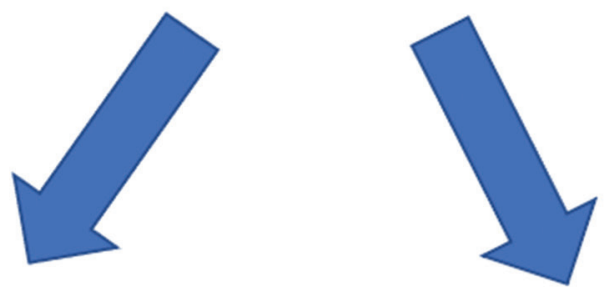

\section{Findings compatible with a specific disease}

Treatment directed towards that specific disease

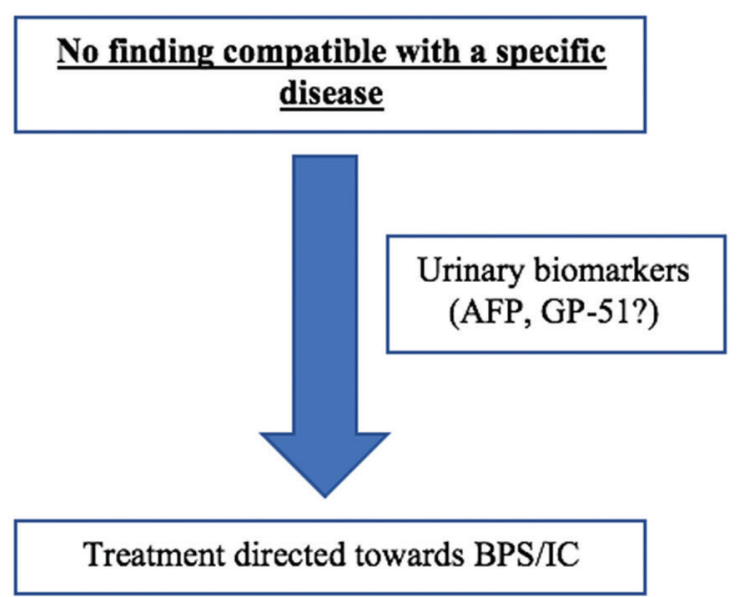

The success (more than 50\% of symptomatic improvement)

to BPS/IC, except nocturia. The treatment efficacy of PPS rates of oral PPS in terms of the effect it had on pelvic pain, urgency and day and night time frequency have been reported to be $37 \%, 28 \%, 54 \%$ and $48 \%$, respectively in a meta-analysis that included approximately 500 patients. It was found to be superior to placebo for every symptom that may be attributable becomes clinically detectable in 3-6 months. It has been shown that PPS performs better in BPS/IC type $3 \mathrm{C}$ than in non-lesion type BPS/IC. Treatment response has been correlated more with treatment duration, rather than dosage (76). 


\begin{tabular}{|c|c|c|}
\hline \multicolumn{2}{|l|}{ Clinical phenotype } & Possible treatment options \\
\hline \multicolumn{2}{|l|}{ Urinary* } & $\begin{array}{l}\text { Behavioural treatment, Anticholinergics, Intravesicular treatment (Heparin, DMSO, HA, CS, PPS, } \\
\text { Oxybutynin), Hydrodistension, Botulinum toxin A, Sacral neuromodulation, Radical surgery }\end{array}$ \\
\hline \multicolumn{2}{|l|}{ Psychosocial } & Stress management and psychosocial support \\
\hline \multirow{2}{*}{ Organ-specific* } & Hunner's lesion (-) & $\begin{array}{l}\text { Amitriptyline, Cimetidine, Hydroxyzine, PPS, Quercetin, Intravesicular agents (DMSO, Heparin, HA, } \\
\text { CS, alkalinised lidocaine, PPS), Hydrodistension, Botulinum toxin A, Radical surgery }\end{array}$ \\
\hline & Hunner's lesion (+) & $\begin{array}{l}\text { Cyclosporin A, Endoscopic treatment (Fulguration, laser ablation, resection, steroid injection), } \\
\text { Hyperbaric oxygen, Radical surgery }\end{array}$ \\
\hline \multicolumn{2}{|l|}{ Infectious } & Antibiotic(s) \\
\hline \multicolumn{2}{|c|}{ Neurologic/systemic } & Gabapentanoids, Hydroxyzine, Cimetidine, Sacral neuromodulation \\
\hline \multicolumn{2}{|l|}{ Sensitivity } & Pelvic floor physiotherapy, Massage therapy, Acupuncture, Trigger point injections \\
\hline
\end{tabular}

Table 4. Oral and conservative treatment options in BPS/IC and the grades of recommendation assigned to each option in the clinical guidelines (3)

\begin{tabular}{|c|c|c|c|c|c|c|}
\hline \multicolumn{2}{|c|}{ Treatment options } & \multirow{2}{*}{$\begin{array}{l}\text { EAU } \\
\text { A }\end{array}$} & \multirow{2}{*}{$\begin{array}{l}\text { AUA } \\
\text { Clinical principle }\end{array}$} & \multirow{2}{*}{$\mathrm{ICI}$} & \multirow{2}{*}{$\begin{array}{l}\text { RCOG } \\
-\end{array}$} & \multirow{2}{*}{$\begin{array}{l}\text { CUA } \\
\text { A }\end{array}$} \\
\hline \multirow{6}{*}{$\begin{array}{l}\text { Conservative } \\
\text { treatment }\end{array}$} & $\begin{array}{l}\text { Multimodal treatment (pain } \\
\text { management, behavioural, } \\
\text { psychosocial and educational) }\end{array}$ & & & & & \\
\hline & Stress management & - & Clinical principle & $\mathrm{C}$ & $\mathrm{D}$ & B \\
\hline & Individualised diet advices & C & Clinical principle & C & $\mathrm{D}$ & B \\
\hline & Physiotherapy & $A$ & Standard & $\mathrm{C}$ & $\mathrm{B}$ & B \\
\hline & Acupuncture & - & - & - & $\mathrm{D}$ & $\mathrm{B}$ \\
\hline & Pelvic floor-trigger point injections & - & - & - & - & $\mathrm{D}$ \\
\hline \multirow{9}{*}{ Oral treatment } & Gabapentin & - & - & $\mathrm{C}$ & - & C \\
\hline & Amitriptyline & A & Optional & $\mathrm{B}$ & $\mathrm{B}$ & B \\
\hline & Cimetidine & Limited benefit & Optional & C & $\mathrm{B}$ & $\mathrm{B}$ \\
\hline & Hydroxyzine & - & Optional & $\mathrm{D}$ & Not recommended & B \\
\hline & Sodium pentosan polysulphate (PPS) & $A$ & Optional & $\mathrm{D}$ & Not recommended & $\mathrm{D}$ \\
\hline & PPS + subcutaneous heparin & A & - & - & - & - \\
\hline & Antibiotic(s) & - & Not recommended & D & Not recommended & - \\
\hline & Suplatast tosilate & - & - & $\mathrm{D}$ & - & - \\
\hline & $\begin{array}{l}\text { Glucocorticoids } \\
\text { (long-term) }\end{array}$ & $\begin{array}{l}\text { Not } \\
\text { recommended }\end{array}$ & Not recommended & - & Not recommended & - \\
\hline
\end{tabular}

\section{Gabapentanoids}

Studies with relatively lower level of evidence have shown that gabapentin may alleviate the pelvic pain associated with BPS/IC in $50 \%$ of the patients (77).

\section{Quercetin}

Based on the positive results it had achieved within the context of male chronic pelvic pain syndrome treatment, quercetin has been tested for the management of BPS/IC with some success in some observational studies (78).

\section{2.b. Intravesicular Treatment Options}

Intravesicular treatment alternatives may be utilised when oral options fail or if a multimodal approach is deemed necessary for a better outcome.

\section{Dimethylsulfoxide (DMSO)}

DMSO is an organic compound with anti-inflammatory and analgesic effects. It is instilled intravesically $(50 \mathrm{~mL}$ of $50 \%$ solution, left inside the bladder for 30-60 minutes, weekly 
Table 5. Intravesicular treatment options in BPS/IC and the grades of recommendation assigned to each option in the clinical guidelines (62)

\begin{tabular}{|c|c|c|c|c|c|c|}
\hline \multicolumn{2}{|c|}{ Treatment options } & \multirow{2}{*}{$\begin{array}{l}\text { EAU } \\
\text { Not } \\
\text { recommended }\end{array}$} & \multirow{2}{*}{$\begin{array}{l}\text { AUA } \\
\text { Optional }\end{array}$} & \multirow{2}{*}{$\begin{array}{l}\mathrm{ICI} \\
\mathrm{B}\end{array}$} & \multirow{2}{*}{$\frac{\mathrm{RCOG}}{\mathrm{C}}$} & \multirow{2}{*}{$\begin{array}{l}\text { CUA } \\
\text { B }\end{array}$} \\
\hline \multirow{8}{*}{$\begin{array}{l}\text { Intravesicular } \\
\text { treatment }\end{array}$} & DMSO & & & & & \\
\hline & PPS & $A$ & - & $\mathrm{D}$ & - & $\mathrm{C}$ \\
\hline & $\mathrm{HA}$ & B & - & D & B & C \\
\hline & $\mathrm{CS}$ & B & - & D & D & $\mathrm{Da}$ \\
\hline & Heparin & C & Optional & C & $\mathrm{D}$ & $\mathrm{C}$ \\
\hline & Oxybutynin & Limited benefit & - & D & - & C \\
\hline & BCG & $\begin{array}{l}\text { Not } \\
\text { recommended }\end{array}$ & $\begin{array}{l}\text { Not } \\
\text { recommended }\end{array}$ & $\begin{array}{l}\text { Not } \\
\text { recommended }\end{array}$ & $\begin{array}{l}\text { Not } \\
\text { recommended }\end{array}$ & Not recommended \\
\hline & Capsaicin/ resiniferatoxin & - & - & $\begin{array}{l}\text { Not } \\
\text { recommended }\end{array}$ & $\begin{array}{l}\text { Not } \\
\text { recommended }\end{array}$ & Not recommended \\
\hline
\end{tabular}

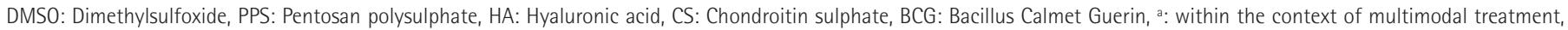
b: in conjunction with sodium bicarbonate, EAU: European Association of Urology, AUA: American Urological Association, ICl: International Consultation on Incontinence, RCOG: Royal College of Obstetricians and Gynaecologists, CUA: Canadian Urological Association

Table 6. Other treatment options in BPS/IC and the grades of recommendation assigned to each option in the clinical guidelines

\begin{tabular}{|c|c|c|c|c|c|c|}
\hline \multicolumn{2}{|l|}{ Treatment options } & \multirow{2}{*}{$\begin{array}{l}\text { EAU } \\
\text { Not } \\
\text { recommended }\end{array}$} & \multirow{2}{*}{$\begin{array}{l}\text { AUA } \\
\text { Optional }\end{array}$} & \multirow{2}{*}{$\frac{\mathrm{ICI}}{\mathrm{C}}$} & \multirow{2}{*}{$\begin{array}{l}\text { RCOG } \\
\text { D }\end{array}$} & \multirow{2}{*}{$\begin{array}{l}\text { CUA } \\
\text { C }\end{array}$} \\
\hline Cystoscopic & $\begin{array}{l}\text { Hydrodistension (brief and under low } \\
\text { pressure) }\end{array}$ & & & & & \\
\hline & $\begin{array}{l}\text { Intralesional (Hunner's) triamcinolone } \\
\text { injection }\end{array}$ & - & Recommended & - & - & - \\
\hline \multirow{3}{*}{$\begin{array}{l}\text { Other treatment } \\
\text { options }\end{array}$} & BTX-A & C & Optional & $\mathrm{D}$ & B & C \\
\hline & Sacral neuromodulation & B & Optional & C & $\mathrm{D}$ & C \\
\hline & Cyclosporin A & - & Optional & - & $\mathrm{D}$ & C \\
\hline Radical surgery & $\begin{array}{l}\text { Urinary diversion or augmentation } \\
\text { cystoplasty +/- cystectomy }\end{array}$ & A & Optional & C & $\mathrm{D}$ & C \\
\hline
\end{tabular}

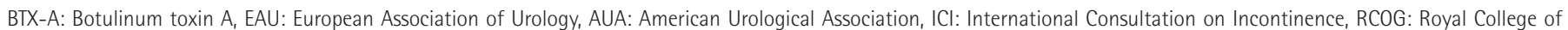
Obstetricians and Gynaecologists, CUA: Canadian Urological Association (3)

administrations for a total of 6 weeks, monthly boosters may be needed) for the treatment of BPS/IC (79). A randomised controlled comparison with normal saline has demonstrated superior objective (93\% vs 35\%, respectively) and subjective (53\% vs 18\%, respectively) improvement rates in the DMSO arm (80). The overall safety profile of DMSO is favourable. Halitosis (garlic-like odor) and a temporary symptomatic flare-up that may be seen following the initial doses represent DMSO-specific side effects (81). Intravesicular DMSO has been approved by the FDA for the treatment of BPS/IC.

\section{Heparin}

Heparin is a structural analogue of GAGs and acts by replenishing the deficient urothelial GAG layer in BPS/IC. Intravesicular heparin treatment has been associated with a symptomatic improvement in the range of 56\%-73\% at 3 months followup $(81,82)$. Parsons et al. (83) have shown that the combined intravesicular administration of lidocaine and heparin can lead to symptomatic relief persisting for 12 hours.

\section{Hyaluronic Acid}

Observational studies have reported symptomatic improvement rates in the range of $30 \%-87 \%$ with hyaluronic acid that is a GAG analogue $(84,85)$. Its intravesicular administration can be combined with other agents, such as chondroitin sulphate (86).

\section{Chondroitin Sulphate}

Chondroitin sulphate is another GAG analogue that is instilled into the bladder for the treatment of BPS/IC. It can lead to symptomatic improvement in $31 \%-39 \%$ of the patients according to the results of placebo-controlled studies $(87,88)$. 
Table 7. Step-wise approach to BPS/IC treatment, ICI, 2017 (62)

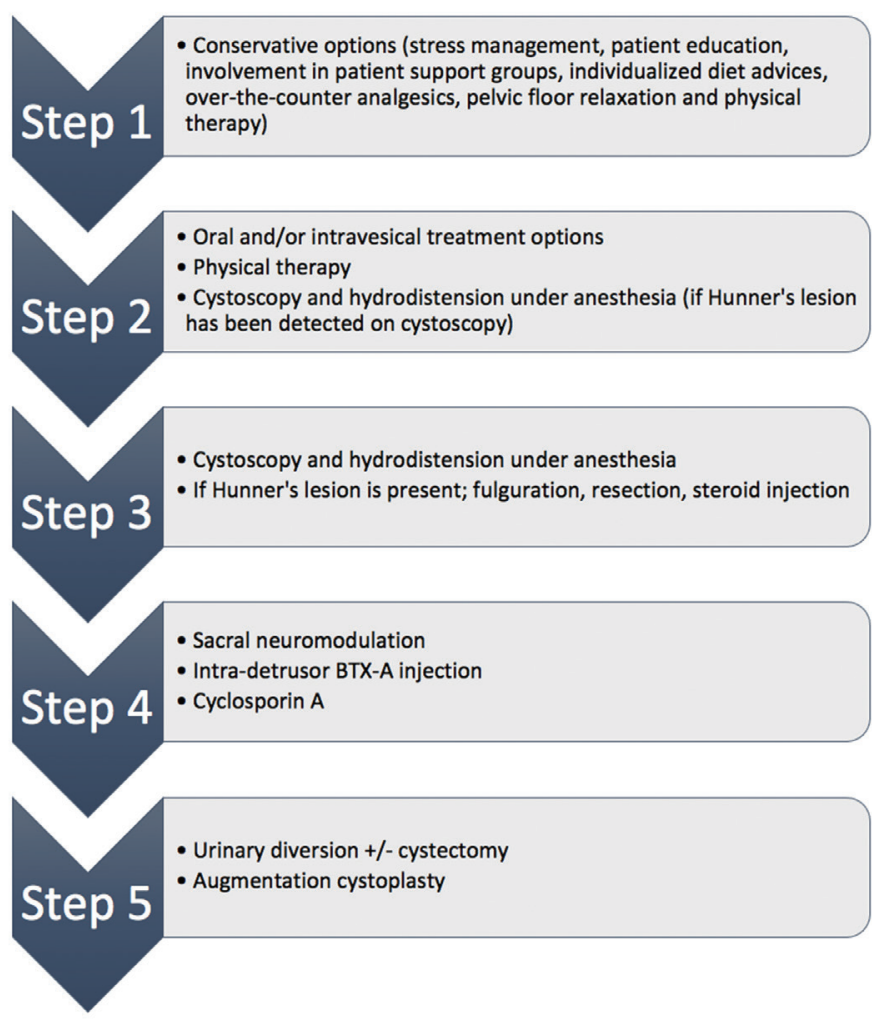

Lidocaine

Lidocaine can be administered intravesically to manage acute exacerbations of BPS/IC. Alkalinisation with sodium bicarbonate or electromotive drug delivery techniques can enhance its diffusion into the bladder wall $(89,90)$. In their placebo-controlled randomised study, Nickel et al. (91) have demonstrated that alkalinised lidocaine can provide profound short-term symptomatic improvement; spanning the 5-day treatment period and the 10-day window post-treatment.

\section{Pentosan Polysulphate (PPS)}

Intravesicular administration can potentiate the clinical efficacy of PPS. A placebo-controlled study has shown $40 \%$ symptomatic improvement rate (92). This rate can be increased to $62 \%$ when combined with oral PPS (93). Combined (oral + intravesicular) PPS treatment has been recommended by the EAU guidelines with a high level of evidence ( $1 b)$ and strong grade of recommendation.

\section{Step 3: Cystoscopic Interventions}

\section{Hydrodistension}

Several observational studies have reported treatment success rates ranging from $18 \%$ to $56 \%$ with cystoscopy and hydrodistension $(94,95)$. However, there is a significant variation
Table 8. Step-wise approach to BPS/IC treatment, AUA, 2015 (63)

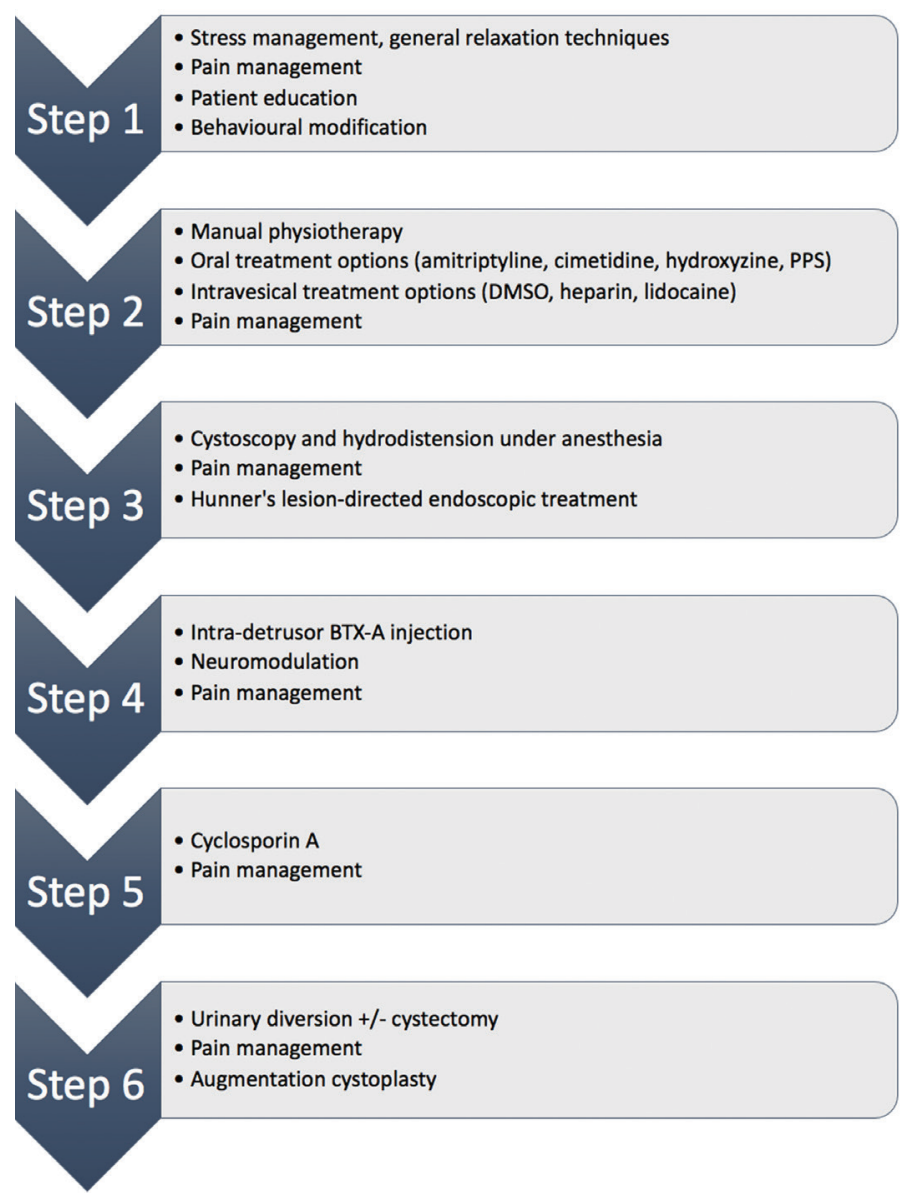

between different hydrodistension protocols. Generally, it is advised that hydrodistension should be kept brief ( 3 minutes) and performed under low pressure $(<80 \mathrm{~cm} \mathrm{H20)}(61)$.

\section{Endoscopic Procedures Directed at Hunner's Lesion(s)}

Targeting cystoscopically detected Hunner's lesion(s) with electrofulguration, neodymium: yttrium-aluminium-garnet laser coagulation and triamcinolone injection can provide relatively higher (70\%-100\%) and more durable (7-12 months) success rates $(96,97)$.

\section{Step 4: Other Treatment Options}

\section{Intradetrusor Botulinum Toxin A (BTX-A) Injection}

Kuo (82) compared intradetrusor BTX-A injection (100U vs 200U) and hydrodistension with hydrodistension alone in a randomised fashion and found out that the success rate at 3 months followup was significantly higher (72\% vs $48 \%$, respectively) in the combined treatment arm. The efficacy was similar between the different BTX-A doses, with $100 \mathrm{U}$ having a more favourable side effect profile. 


\section{Sacral Neuromodulation}

According to the results of observational studies; it is possible to achieve treatment success (more than $50 \%$ of symptomatic improvement) with sacral neuromodulation in $42 \%-95 \%$ of the patients (98). Complications such as infection, migration and malfunction together with a revision surgery rate of 27\%-50\% should be kept in mind while recommending this option to the patients.

\section{Step 5: Cyclosporin A}

The randomised controlled study in which cyclosporin A was compared with PPS in a head-to-head fashion has demonstrated superior results in terms of treatment efficacy in the cyclosporin A arm (59\% vs. 13\%, respectively) (99). Side effect profile (hypertension, nephrotoxicity and immunosuppression) and the need to do regular serum level monitoring are the main obstacles precluding its adoption into routine practice.

\section{Step 6: Radical Surgery}

Urinary diversion $+/$ - cystectomy can be considered as the last treatment option in refractory cases. Alternatively, supratrigonal/ subtrigonal cystectomy and augmentation cystoplasty can also be recommended. Based on the findings gathered in retrospective studies, it can be concluded that radical surgery can be an option for patients who exhibit cystoscopic findings with decreased bladder capacity under anaesthesia and those with severe symptomatology who have exhausted numerous treatment efforts. Patients should be counselled about the possibility of pain persisting despite cystectomy.

\section{Conclusion}

- Patients must be counselled (about the disease's chronic course, need for long-term treatment, the impossibility of achieving cure, etc.) while planning the management strategy.

- A step-wise approach needs to be implemented, as recommended by the guidelines.

- Clinical phenotype-directed, individualised and multimodal approach optimises outcomes.

- Multiple options exist; however, cure is not possible with any of them.

- Aim should be to improve the symptoms and quality of life.

- Further research is warranted.

Peer-review: Externally and internally peer-reviewed.

\section{Authorship Contributions}

Surgical and Medical Practices: T.K., F.T., T.T., T.Ta., Concept: T.K., Ö.A., F.T., T.M.O., T.Ta., Design: T.K., Ö.A., F.T., T.Ta., Data Collection or Processing: T.K., Ö.A., F.T., T.T., T.M.O., T.Ta., Analysis or Interpretation: T.K., Ö.A., F.T., T.T., T.M.O., T.Ta., Literature Search: T.K., Ö.A., F.T., T.T., T.Ta., Writing: T.K., Ö.A., F.T.

Conflict of Interest: No conflict of interest was declared by the authors.

Financial Disclosure: The authors declared that this study received no financial support.

\section{References}

1. Hanno PM. Bladder Pain Syndrome (Interstitial Cystitis) and Related Disorders. In: Wein AJ, Kavoussi LR, Partin AW, Peters CA, editors. CampbellWalsh Urology, 11 ed. Philadelphia, Elsevier; 2016, pp 334-70.

2. Hanno P, Dinis P, Lin A, Nickel C, Nordling J, van Ophoven A, Ueda T. Bladder Pain Syndrome. In: Abrams P, Cardozo L, Khoury S, Wein A. Incontinence. Bristol UK, International Incontinece Society, 2013, pp 1581-1650.

3. Malde S, Palmisani S, Al-Kaisy A, Sahai A. Guideline of guidelines: bladder pain syndrome. BJU Int 2018;122:729-743.

4. Nordling J, Fall M, Hanno P. Global concepts of bladder pain syndrome (interstitial cystitis). World J Urol 2012;30:457-464.

5. Engeler DBA, Baranowski AP, Borovicka J, Cottrell AM, Dinis-Oliveira $P$, Elneil S, Hughes J, Messelink EJ, de C Williams AC. EAU Guidelines on Chronic Pelvic Pain. European Association of Urology, 2018.

6. Jones CA, Nyberg L. Epidemiology of interstitial cystitis. Urology 1997;49:29.

7. Curhan GC, Speizer FE, Hunter DJ, Curhan SG, Stampfer MJ. Epidemiology of interstitial cystitis: a population based study. Journal Urol 1999;161:549-52.

8. Clemens J, Payne C, Pace C. Prevalence of self-reported interstitial cystitis in a nationally representative United States Survey. Berlin/Heidelberg, Springer, 2005. pp 173.

9. Link CL, Pulliam SJ, Hanno PM, Hall SA, Eggers PW, Kusek JW, Kinlay JB. Prevalence and psychosocial correlates of symptoms suggestive of painful bladder syndrome: results from the Boston area community health survey. J Urol 2008;180:599-606

10. Suskind AM, Berry SH, Ewing BA, Elliott MN, Suttorp MJ, Clemens JQ. The prevalence and overlap of interstitial cystitis/bladder pain syndrome and chronic prostatitis/chronic pelvic pain syndrome in men: results of the RAND Interstitial Cystitis Epidemiology male study. J Urol 2013;189:141-145.

11. Clemens JQ, Meenan RT, O'Keeffe Rosetti MC, Brown SO, Gao SY, Calhoun EA. Prevalence of interstitial cystitis symptoms in a managed care population. J Urol 2005; 174:576-580.

12. Ito T, Miki M, Yamada T. Interstitial cystitis in Japan. BJU Int 2000;86:634637.

13. Geist RW, Antolak SJ Jr. Interstitial cystitis in children. J Urol 1970;104:922925.

14. Warren JW, Jackson $T L$, Langenberg $P$, Meyers DJ, Xu J. Prevalence of interstitial cystitis in first-degree relatives of patients with interstitial cystitis. Urology 2004;63:17-21.

15. Clemens JQ, Meenan RT, Rosetti MC, Gao SY, Calhoun EA. Prevalence and incidence of interstitial cystitis in a managed care population. J Urol 2005;173:98-102

16. Oravisto KJ. Epidemiology of interstitial cystitis. Ann Chir Gynaecol Fenn 1975;64:75-77.

17. Roberts RO, Bergstralh EJ, Bass SE, Lightner DJ, Lieber MM, Jacobsen SJ. Incidence of physician-diagnosed interstitial cystitis in Olmsted County: a community-based study. BJU Int 2003;91:181-185. 
18. Hand JR. Interstitial cystitis; report of 223 cases (204 women and 19 men). J Urol 1949;61:291-310.

19. Hanno PM, Landis JR, Matthews-Cook Y, Kusek J, Nyberg L Jr. The diagnosis of interstitial cystitis revisited: lessons learned from the National Institutes of Health Interstitial Cystitis Database study. J Urol 1999;161:553-557.

20. Barry MJ, Link CL, McNaughton-Collins MF, McKinlay JB, Boston Area Community Health I. Overlap of different urological symptom complexes in a racially and ethnically diverse, community-based population of men and women. BJU Int 2008;101:45-51.

21. Song $Y$, Zhang $W, X u B$, Hao L, Song J. Prevalence and correlates of painful bladder syndrome symptoms in Fuzhou Chinese women. Neurourol Urodyn 2009;28:22-25.

22. Berry $S H$, Elliott MN, Suttorp $M$, Bogart LM, Stoto MA, Eggers $P$, Nyberg $L$, Clemens J0. Prevalence of symptoms of bladder pain syndrome/interstitial cystitis among adult females in the United States. J Urol 2011;186:540-544.

23. Rodriguez MA, Afari N, Buchwald DS, National Institute of D, Digestive, Kidney Diseases Working Group on Urological Chronic Pelvic P. Evidence for overlap between urological and nonurological unexplained clinical conditions. J Urol 2009;182:2123-2131.

24. Warren JW, Clauw DJ, Wesselmann U, Langenberg PW, Howard FM, Morozov V. Sexuality and reproductive risk factors for interstitial cystitis/painful bladder syndrome in women. Urology 2011;77:570-575.

25. Lai HH, North CS, Andriole GL, Sayuk GS, Hong BA. Polysymptomatic, polysyndromic presentation of patients with urological chronic pelvic pain syndrome. J Urol 2012;187:2106-2112.

26. Alagiri M, Chottiner S, Ratner V, Slade D, Hanno PM. Interstitial cystitis: unexplained associations with other chronic disease and pain syndromes. Urology 1997;49:52-57.

27. Clauw DJ, Schmidt M, Radulovic D, Singer A, Katz P, Bresette J. The relationship between fibromyalgia and interstitial cystitis. J Psychiatr Res 1997;31:125-131.

28. Aaron LA, Buchwald D. A review of the evidence for overlap among unexplained clinical conditions. Ann Intern Med 2001;134:868-881.

29. Aaron LA, Herrell R, Ashton S, Belcourt M, Schmaling K, Goldberg J, Buchwald D. Comorbid clinical conditions in chronic fatigue: a co-twin control study. J Gen Intern Med 2001;16:24-31.

30. Buffington CA. Comorbidity of interstitial cystitis with other unexplained clinical conditions. J Urol 2004;172(4 Pt 1):1242-1248.

31. Wu EQ, Birnbaum $H$, Kang YJ, Parece A, Mallett D, Taitel $H$, Evans RJ. A retrospective claims database analysis to assess patterns of interstitial cystitis diagnosis. Curr Med Res Opin 2006;22:495-500.

32. Clemens JQ, Meenan RT, O'Keeffe Rosetti MC, Kimes TA, Calhoun EA. Casecontrol study of medical comorbidities in women with interstitial cystitis. J Urol 2008;179:2222-2225.

33. Warren JW, Howard FM, Cross RK, Good JL, Weissman MM, Wesselmann U, Langenberg P, Greenberg P, Clauw DJ. Antecedent nonbladder syndromes in case-control study of interstitial cystitis/painful bladder syndrome. Urology 2009;73:52-57.

34. Weisman MH, McDanald EC, Wilson CB. Studies of the pathogenesis of interstitial cystitis, obstructive uropathy, and intestinal malabsorption in a patient with systemic lupus erythematosus. Am J Med 1981;70:875-881.

35. Meulders Q, Michel C, Marteau P, Grange JD, Mougenot B, Ronco P, Mignon F. Association of chronic interstitial cystitis, protein-losing enteropathy and paralytic ileus with seronegative systemic lupus erythematosus: case report and review of the literature. Clin Nephrol 1992;37:239-244.

36. Van de Merwe J, Kamerling R, Arendsen E, Mulder D, Hooijkaas H. Sjogren's syndrome in patients with interstitial cystitis. J Rheumatol 1993;20:962966.
37. Leppilahti M, Tammela TL, Huhtala H, Kiilholma P, Leppilahti K, Auvinen A. Interstitial cystitis-like urinary symptoms among patients with Sjogren's syndrome: a population-based study in Finland. Am J Med 2003;115:62-65.

38. Nickel JC, Tripp DA, Pontari M, Moldwin R, Mayer R, Carr LK, Doggweiler R, Yang CC, Mishra N, Nordling J. Interstitial cystitis/painful bladder syndrome and associated medical conditions with an emphasis on irritable bowel syndrome, fibromyalgia and chronic fatigue syndrome. J Urol 2010;184:1358-1363.

39. Nickel JC, Tripp DA, Pontari M, Moldwin R, Mayer R, Carr LK, Doggweiler R, Yang CC, Mishra N, Nordling J. Psychosocial phenotyping in women with interstitial cystitis/painful bladder syndrome: a case control study. J Urol 2010;183:167-172.

40. Erickson DR, Morgan KC, Ordille S, Keay SK, Xie SX. Nonbladder related symptoms in patients with interstitial cystitis. J Urol 2001;166:557-561.

41. Peters KM, Killinger KA, Mounayer MH, Boura JA. Are ulcerative and nonulcerative interstitial cystitis/painful bladder syndrome 2 distinct diseases? A study of coexisting conditions. Urology 2011;78:301-308.

42. Weissman MM, Gross R, Fyer A, Heiman GA, Gameroff MJ, Hodge SE, Gameroff MJ, Hodge SE, Kaufman D, Kaplan SA, Wickramaratne PJ. Interstitial cystitis and panic disorder: a potential genetic syndrome. Arch Gen Psychiatr 2004;61:273-279.

43. Watkins KE, Eberhart N, Hilton L, Suttorp MJ, Hepner KA, Clemens JQ, Berry SH. Depressive disorders and panic attacks in women with bladder pain syndrome/interstitial cystitis: a population-based sample. Gen Hosp Psychiatr 2011;33:143-149.

44. Keller JJ, Chen YK, Lin HC. Comorbidities of bladder pain syndrome/ interstitial cystitis: a population-based study. BJU Int 2012;110:E903-E909.

45. Chung KH, Liu SP, Lin HC, Chung SD. Bladder pain syndrome/interstitial cystitis is associated with anxiety disorder. Neurourol Urodyn 2014;33:101105.

46. Ottem DP, Carr LK, Perks AE, Lee P, Teichman JM. Interstitial cystitis and female sexual dysfunction. Urology 2007;69:608-610.

47. Peters KM, Killinger KA, Carrico DJ, Ibrahim IA, Diokno AC, Graziottin A. Sexual function and sexual distress in women with interstitial cystitis: a case-control study. Urology 2007;70:543-547.

48. Bogart LM, Suttorp MJ, Elliott MN, Clemens JQ, Berry SH. Prevalence and correlates of sexual dysfunction among women with bladder pain syndrome/interstitial cystitis. Urology 2011;77:576-580.

49. Koziol JA, Clark DC, Gittes RF, Tan EM. The natural history of interstitial cystitis: a survey of 374 patients. J Urol 1993;149:465-469.

50. Propert KJ, Schaeffer AJ, Brensinger CM, Kusek JW, Nyberg LM, Landis JR. A prospective study of interstitial cystitis: results of longitudinal followup of the interstitial cystitis data base cohort. The Interstitial Cystitis Data Base Study Group. J Urol 2000;163:1434-1439.

51. Driscoll A, Teichman JM. How do patients with interstitial cystitis present? J Urol 2001;166:2118-2120.

52. Warren JW, Diggs C, Brown V, Meyer WA, Markowitz S, Greenberg P. Dysuria at onset of interstitial cystitis/painful bladder syndrome in women. Urology 2006;68:477-481.

53. Bade J, Ishizuka O, Yoshida M. Future research needs for the definition/ diagnosis of interstitial cystitis. Int J Urol 2003;10 Suppl:S31-S34.

54. van de Merwe JP, Nordling J, Bouchelouche $P$, Bouchelouche $K$, Cervigni M, Daha LK, Daha LK, Elneil S, Fall M, Hohlbrugger G, Irwin P, Mortensen S, van Ophoven A, Osborne JL, Peeker R, Richter B, Riedl C, Sairanen J, Tinzl $\mathrm{M}$, Wyndaele JJ. Diagnostic criteria, classification, and nomenclature for painful bladder syndrome/interstitial cystitis: an ESSIC proposal. Eur Urol 2008;53:60-67.

55. Abrams P, Cardozo L, Wagg A, Wein A. Bladder pain syndrome, 6th ed. Tokyo, International Continence Society, 2017. 
56. Moskowitz MO, Byrne DS, Callahan HJ, Parsons CL, Valderrama E, Moldwin RM. Decreased expression of a glycoprotein component of bladder surface mucin (GP1) in interstitial cystitis. J Urol 1994;151:343-345.

57. Keay S, Zhang CO, Hise MK, Hebel JR, Jacobs SC, Gordon D, Whitmore K, Bodison S, Gordon N, Warren JW. A diagnostic in vitro urine assay for interstitial cystitis. Urology 1998;52:974-978.

58. Chai TC, Zhang C, Warren JW, Keay S. Percutaneous sacral third nerve root neurostimulation improves symptoms and normalizes urinary HB-EGF levels and antiproliferative activity in patients with interstitial cystitis. Urology 2000;55:643-646.

59. Keay S, Zhang CO, Marvel R, Chai T. Antiproliferative factor, heparinbinding epidermal growth factor-like growth factor, and epidermal growth factor: sensitive and specific urine markers for interstitial cystitis. Urology 2001;57:104.

60. Nickel JC, Irvine-Bird K, Jianbo L, Shoskes DA. Phenotype-directed management of interstitial cystitis/bladder pain syndrome. Urology 2014;84:175-179.

61. Cox A, Golda N, Nadeau G, Curtis Nickel J, Carr L, Corcos J, Teichman J. CUA guideline: Diagnosis and treatment of interstitial cystitis/bladder pain syndrome. Can Urol Assoc J 2016;10:E136-E55.

62. Hanno $P$, Cervigni $M$, Dinis $P$, Lin $A$, Nickel JC, Nordling J, van Ophoven A, Ueda T. Bladder Pain Syndrome. In: Abrams P, Cardozo L, Wagg A, Wein A. International Consultation on Incontinence. Tokyo, International Continence Society, 2017, pp 2203-2302.

63. Hanno PM, Erickson D, Moldwin R, Faraday MM, American Urological A. Diagnosis and treatment of interstitial cystitis/bladder pain syndrome: AUA guideline amendment. J Urol 2015;193:1545-1553.

64. Bosch PC. Examination of the significant placebo effect in the treatment of interstitial cystitis/bladder pain syndrome. Urology 2014;84:321-326.

65. Bassaly R, Downes K, Hart S. Dietary consumption triggers in interstitial cystitis/bladder pain syndrome patients. Female Pelvic Med Reconstr Surg 2011;17:36-39.

66. Hanno $P$, Cervigni $M$, Dinis $P$, Lin $A$, Nickel JC, Nordling J, Van Ophoven $A$, Ueda T. Bladder Pain Syndrome. In: Abrams P, Cardozo L, Wagg A, Wein A. Incontinence: International Continence Society; 2016, pp 2203-2302.

67. Chaiken DC, Blaivas JG, Blaivas ST. Behavioral therapy for the treatment of refractory interstitial cystitis. J Urol 1993;149:1445-1448.

68. Rabin C, O'Leary A, Neighbors C, Whitmore K. Pain and depression experienced by women with interstitial cystitis. Women Health 2000;31:67-81.

69. Michael YL, Kawachi I, Stampfer MJ, Colditz GA, Curhan GC. Quality of life among women with interstitial cystitis. J Urology 2000;164:423-427.

70. Weiss JM. Pelvic floor myofascial trigger points: manual therapy for interstitial cystitis and the urgency-frequency syndrome. J Urol $2001 ; 166: 2226-2231$

71. Oyama IA, Rejba A, Lukban JC, Fletcher E, Kellogg-Spadt S, Holzberg AS, Whitmore KE. Modified Thiele massage as therapeutic intervention for female patients with interstitial cystitis and high-tone pelvic floor dysfunction. Urology 2004;64:862-865.

72. van Ophoven A, Pokupic $S$, Heinecke A, Hertle L. A prospective, randomized, placebo controlled, double-blind study of amitriptyline for the treatment of interstitial cystitis. J Urol 2004;172:533-536.

73. Foster HE, Jr., Hanno PM, Nickel JC, Payne CK, Mayer RD, Burks DA, Yang CC, Chai TC, Kreder KJ, Peters KM, Lukacz ES, FitzGerald MP, Cen L, Landis LR, Propert KJ, Yang W, Kusek WJ, Nyberg LM, Interstitial Cystitis Collaborative Research Network. Effect of amitriptyline on symptoms in treatment naive patients with interstitial cystitis/painful bladder syndrome. J Urol 2010;183:1853-1858.

74. Thilagarajah R, Witherow RO, Walker MM. Oral cimetidine gives effective symptom relief in painful bladder disease: a prospective, randomized, double-blind placebo-controlled trial. BJU int 2001;87:207-212.
75. Sant GR, Propert KJ, Hanno PM, Burks D, Culkin D, Diokno AC, Hardy $C_{\text {, }}$ Landis JR, Mayer R, Madigan R, Messing EM, Peters K, Theoharides TC, Warren J, Wein AJ, Steers W, Kusek JW, Nyberg LM, Interstitial Cystitis Clinical Trials Group. A pilot clinical trial of oral pentosan polysulfate and oral hydroxyzine in patients with interstitial cystitis. J Urol 2003;170:810815.

76. Nickel JC, Herschorn $\mathrm{S}$, Whitmore $\mathrm{KE}$, Forrest JB, Hu P, Friedman $\mathrm{AJ}$, Baseman AS. Pentosan polysulfate sodium for treatment of interstitial cystitis/bladder pain syndrome: insights from a randomized, double-blind, placebo controlled study. J Urol 2015;193:857-862.

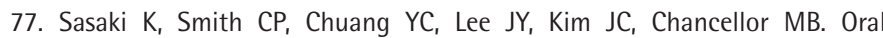
gabapentin (neurontin) treatment of refractory genitourinary tract pain. Tech Urol 2001;7:47-49.

78. Katske F, Shoskes DA, Sender M, Poliakin R, Gagliano K, Rajfer J. Treatment of interstitial cystitis with a quercetin supplement. Tech Urol 2001;7:44-46.

79. Erickson DR. Bladder pain syndrome: Current terminology, diagnosis, and treatment. AUA Update Series, 2009.

80. Perez-Marrero R, Emerson LE, Feltis JT. A controlled study of dimethyl sulfoxide in interstitial cystitis. J Urol 1988;140:36-39.

81. Mouracade P, Saussine C. [Interstitial cystitis in 2008]. Prog Urol 2008;18:418-425.

82. Kuo HC. Urodynamic results of intravesical heparin therapy for women with frequency urgency syndrome and interstitial cystitis. J Formos Med Assoc 2001;100:309-314.

83. Parsons $C L$, Zupkas P, Proctor J, Koziol J, Franklin A, Giesing D, Davis $E_{1}$ Lakin CM, Kahn BS, Garner WJ. Alkalinized lidocaine and heparin provide immediate relief of pain and urgency in patients with interstitial cystitis. J Sex Med 2012;9:207-212.

84. Kallestrup EB, Jorgensen SS, Nordling J, Hald T. Treatment of interstitial cystitis with Cystistat: a hyaluronic acid product. Scand J Urol Nephrol 2005;39:143-147.

85. Kim A, Lim B, Song $M$, Choo MS. Pretreatment features to influence effectiveness of intravesical hyaluronic Acid instillation in refractory interstitial cystitis/painful bladder syndrome. Int Neurourol J 2014;18:163167.

86. Gulpinar O, Kayis A, Suer E, Gokce MI, Guclu AG, Arikan N. Clinical comparision of intravesical hyaluronic acid and hyaluronic acid-chondroitin sulphate therapy for patients with bladder pain syndrome/interstitital cystitis. Can Urol Assoc J 2014;8:E610-e614.

87. Nickel JC, Egerdie RB, Steinhoff G, Palmer B, Hanno P. A multicenter randomized, double-blind, parallel group pilot evaluation of the efficacy and safety of intravesical sodium chondroitin sulfate versus vehicle control in patients with interstitial cystitis/painful bladder syndrome. Urology 2010;76:804-809.

88. Nickel JC, Hanno P, Kumar K, Thomas H. Second multicenter, randomized, double-blind, parallel-group evaluation of effectiveness and safety of intravesical sodium chondroitin sulfate compared with inactive vehicle control in subjects with interstitial cystitis/bladder pain syndrome. Urology 2012;79:1220-1224.

89. Henry R, Patterson L, Avery N, Tanzola R, Tod D, Hunter D, Nickel JC, Morales A. Absorption of alkalized intravesical lidocaine in normal and inflamed bladders: a simple method for improving bladder anesthesia. J Urol 2001;165(6 Pt 1):1900-1903.

90. Rosamilia A, Dwyer PL, Gibson J. Electromotive drug administration of lidocaine and dexamethasone followed by cystodistension in women with interstitial cystitis. Int Urogynecol J Pelvic Floor Dysfunct 1997;8:142-145.

91. Nickel JC, Moldwin R, Lee $S$, Davis EL, Henry RA, Wyllie MG. Intravesical alkalinized lidocaine (PSD597) offers sustained relief from symptoms of interstitial cystitis and painful bladder syndrome. BJU Int 2009;103:910918. 
92. Bade JJ, Laseur M, Nieuwenburg A, van der Weele LT, Mensink HJ. A placebocontrolled study of intravesical pentosanpolysulphate for the treatment of interstitial cystitis. Br J Urol 1997;79:168-171.

93. Davis EL, El Khoudary SR, Talbott EO, Davis J, Regan U. Safety and efficacy of the use of intravesical and oral pentosan polysulfate sodium for interstitial cystitis: a randomized double-blind clinical trial. J Urol 2008;179:177-185.

94. Cole EE, Scarpero HM, Dmochowski RR. Are patient symptoms predictive of the diagnostic and/or therapeutic value of hydrodistention? Neurourol Urodyn 2005;24:638-642.

95. Aihara K, Hirayama A, Tanaka N, Fujimoto K, Yoshida K, Hirao Y. Hydrodistension under local anesthesia for patients with suspected painful bladder syndrome/interstitial cystitis: safety, diagnostic potential and therapeutic efficacy. Int J Urol 2009;16:947-952.
96. Payne RA, O'Connor RC, Kressin M, Guralnick ML. Endoscopic ablation of Hunner's lesions in interstitial cystitis patients. Can Urol Assoc J 2009;3:473477.

97. Malloy TR, Shanberg AM. Laser therapy for interstitial cystitis. Urol Clin North Am1994;21:141-144.

98. Powell CR, Kreder KJ. Long-term outcomes of urgency-frequency syndrome due to painful bladder syndrome treated with sacral neuromodulation and analysis of failures. J Urol 2010;183:173-176.

99. Sairanen J, Tammela TL, Leppilahti M, Multanen M, Paananen I, Lehtoranta K, Ruutu M. Cyclosporine A and pentosan polysulfate sodium for the treatment of interstitial cystitis: a randomized comparative study. J Urol $2005 ; 174: 2235-2238$ 